FARBTAFELN 



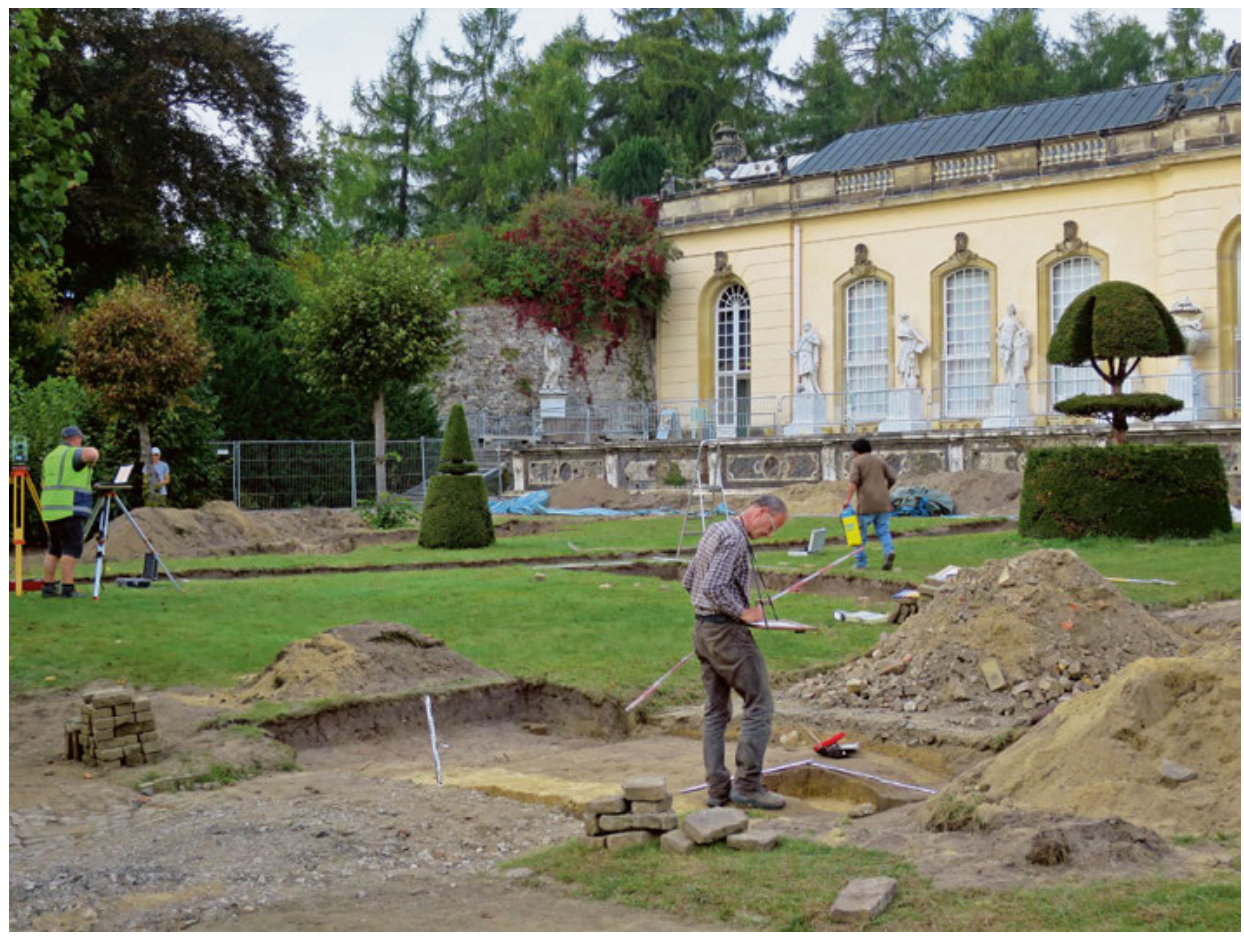

I Gartenarchäologische Untersuchungen zur Restaurierung des Holländischen Gartens unterhalb der Bildergalerie im Park Sanssouci, vgl. Generaldirektion (2014).

II Garten des Königs Snofru in Dahschur Aus: Arnold, Felix (2016): Ein Garten in der Wüste. In: Archäologie Weltweit 2, 32, Abb. 2.

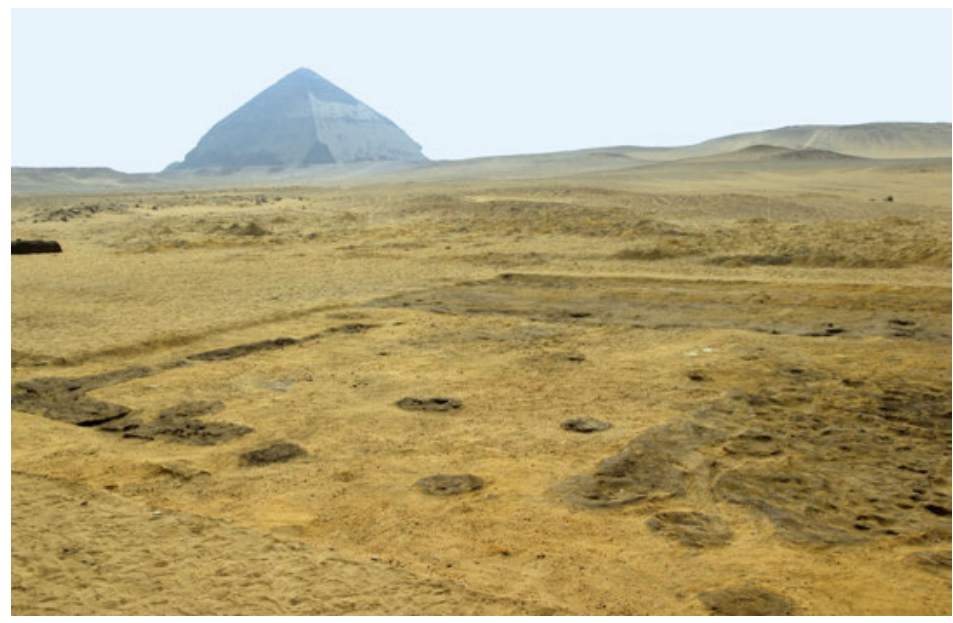

¿ OpenAccess. @ 2019 Reinhard F. Hüttl, Karen David und Bernd Uwe Schneider, Berlin-Brandenburgische Akademie der Wissenschaften, publiziert von De Gruyter. (c) BY-NC-SA Dieses Werk ist lizenziert unter der Creative Commons Attribution-NonCommercial-ShareAlike 4.0 Lizenz. https://doi.org/10.1515/9783110607482-036 


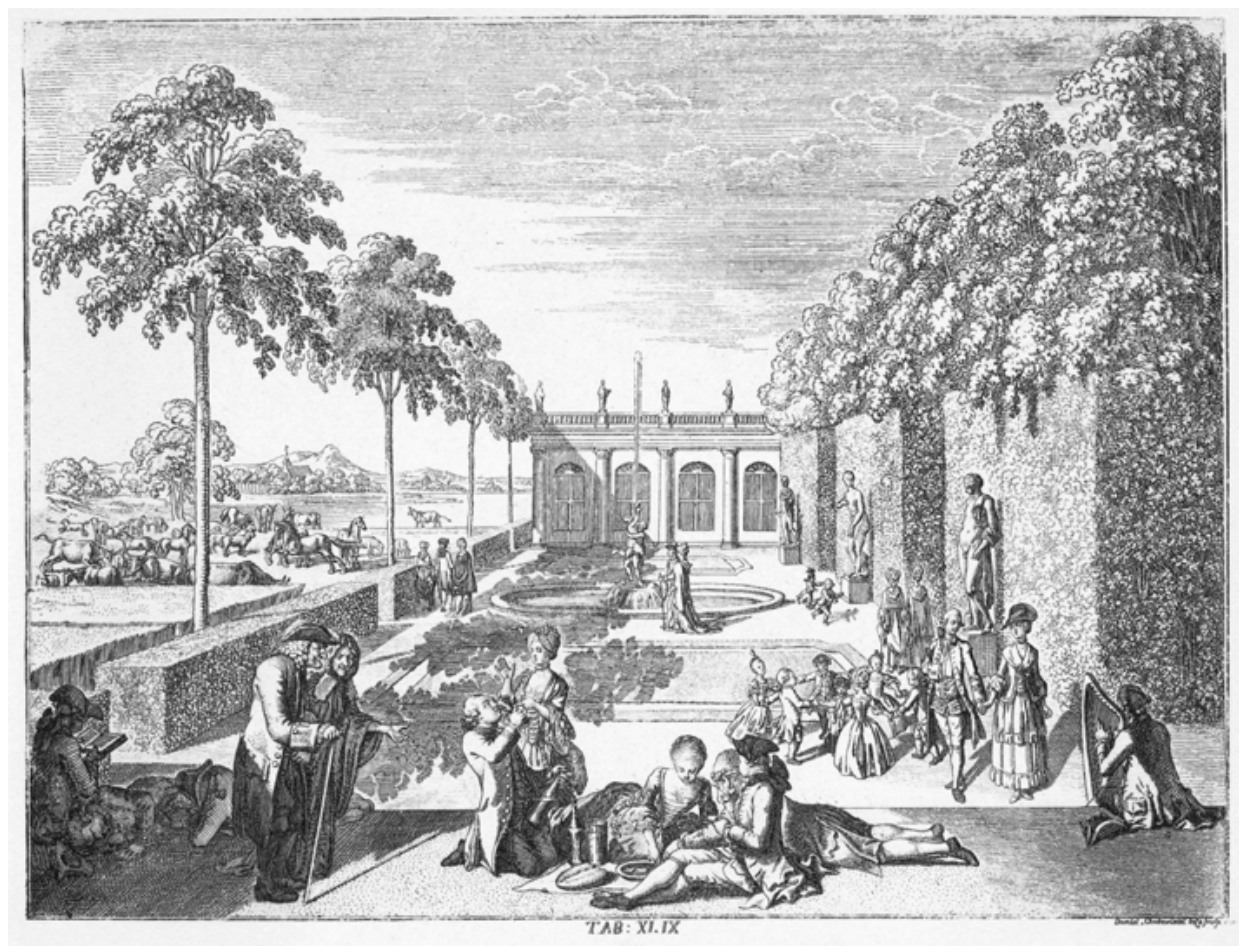

III Schulbuch Basedow. Mit dem Gartenbild »Mancherlei Vergnügungen an der Natur, an dem freundschaftlichen Umgange und an den Werken der Kunst« erklärte Basedow Schulkindern das Schmecken (Picknickszene), das Hören (Tanz zu Musik und Gesang der Vögel), das Sehen und Tasten (Künste mit Farben, Symmetrien und Schönheit) und das Riechen (Blumen, Blüten und Kräuter) (Basedow 1774). 
IV Maschinenbau

in »Feuerland « (orange):

1. Königliche Eisengiesserei (1804),

2. F. A. Egells (1826),

3. A. Borsig (1837),

4. F. A. Pflug (1839),

5. F. Wöhlert (1842),

6. C. Hoppe (1844),

7. L. Schwarzkopf $(1852,1867)$,

8. W. Wedding (1857);

and area of »Voigtland « (pink). Colors added to Liebenow, Wilhelm (1888):

Situations-Plan von der Haupt- und Residenz-Stadt Berlin und Umgegend. Berlin: Schropp.

V Friedrichshain (green) and its context: cemeteries (pink) with Märzgefallenen (bright pink), care of the poor (yellow), breweries (bright blue), small pond (blue), large dry pond (tan), playgrounds (tan). Colors added to Liebenow, W. (1888): SituationsPlan von der Haupt- und ResidenzStadt Berlin und Umgegend. Berlin: Schropp.
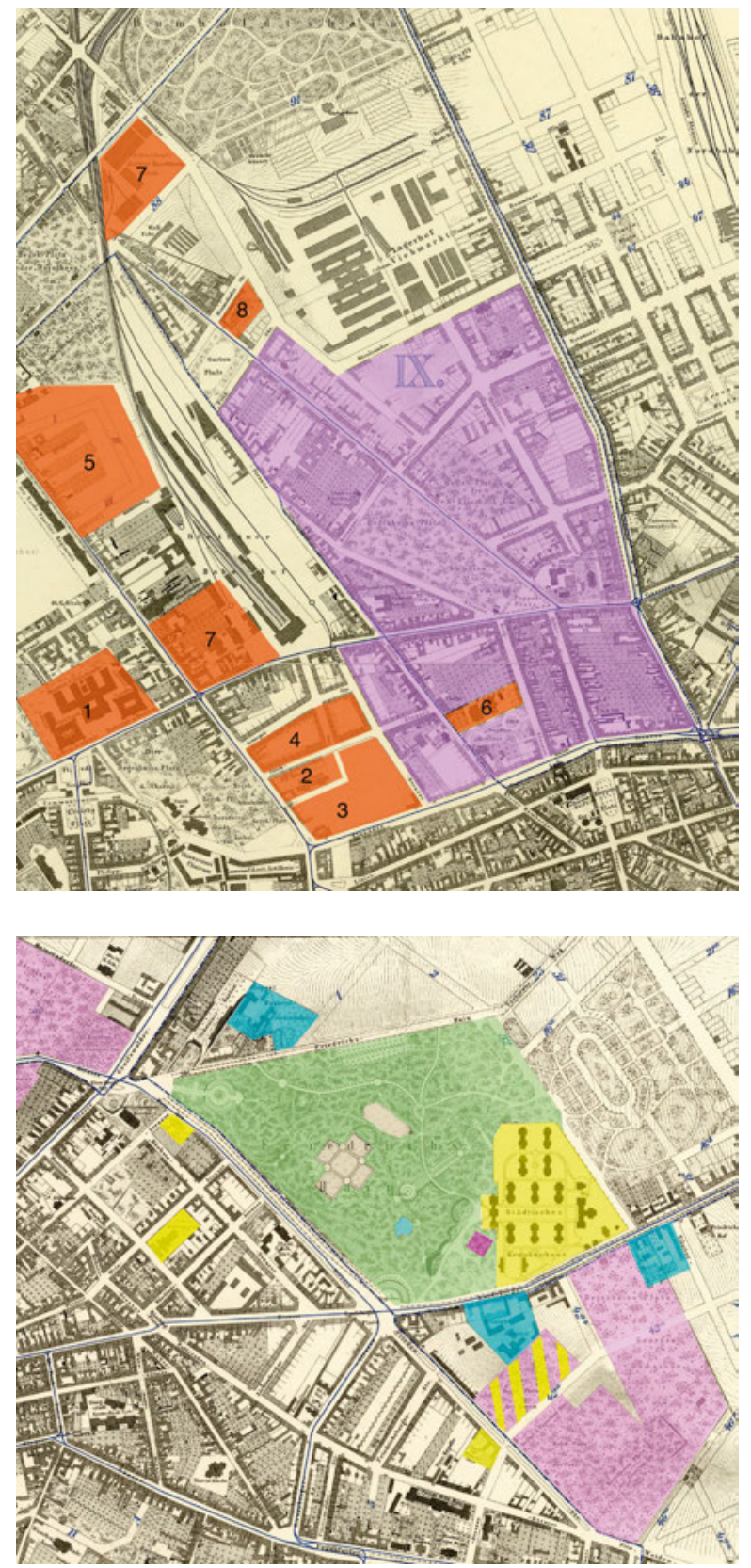

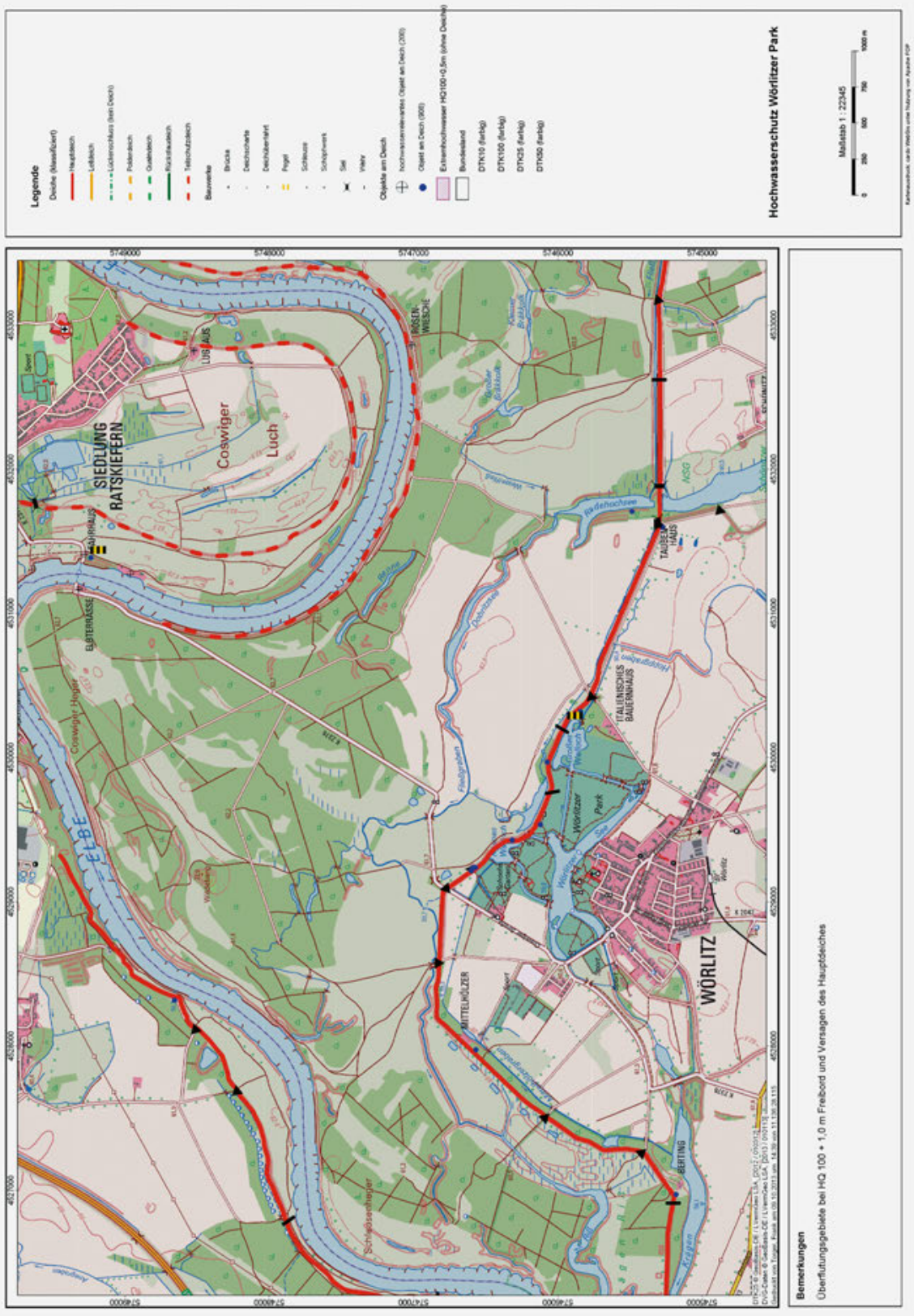

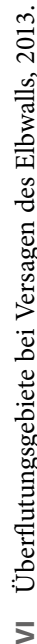




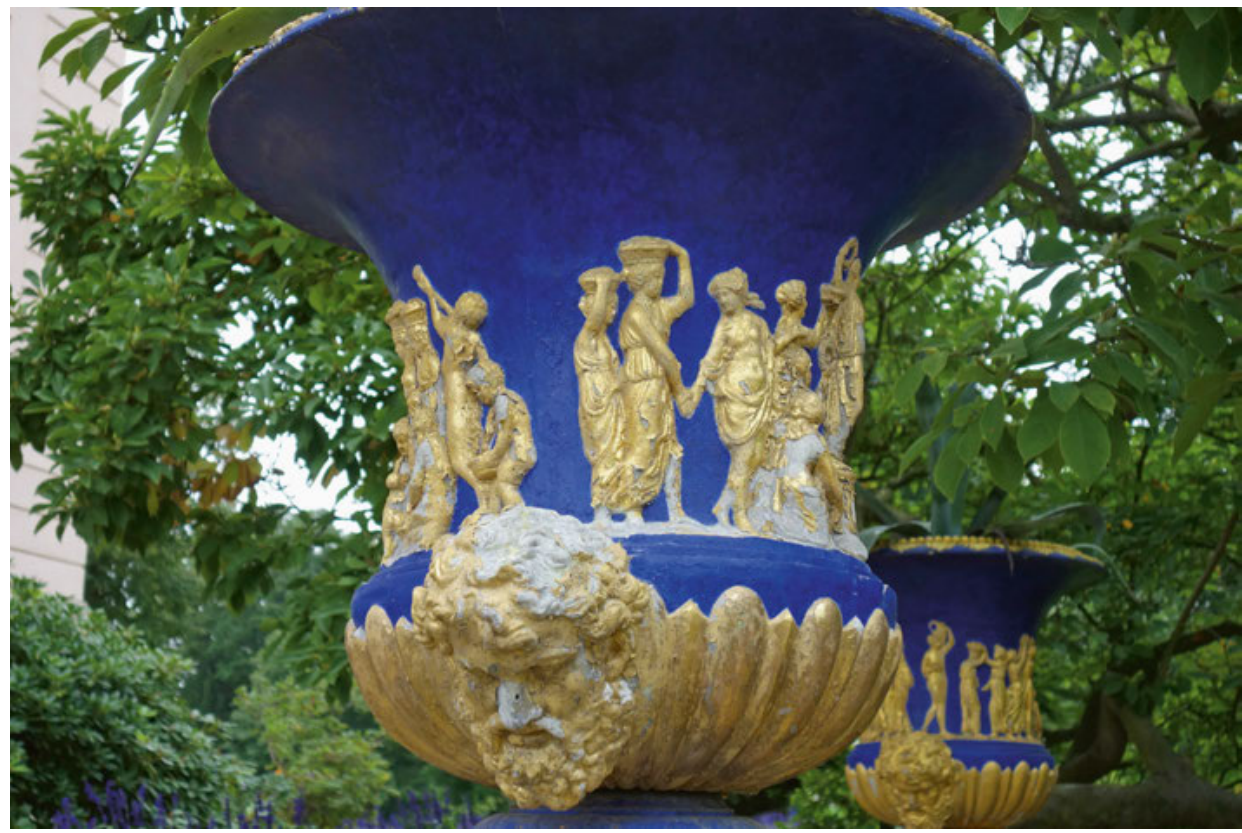

VII Branitz: Figuren in Gold. Vor der Restaurierung: (G1) (G3) (G4) (C9).

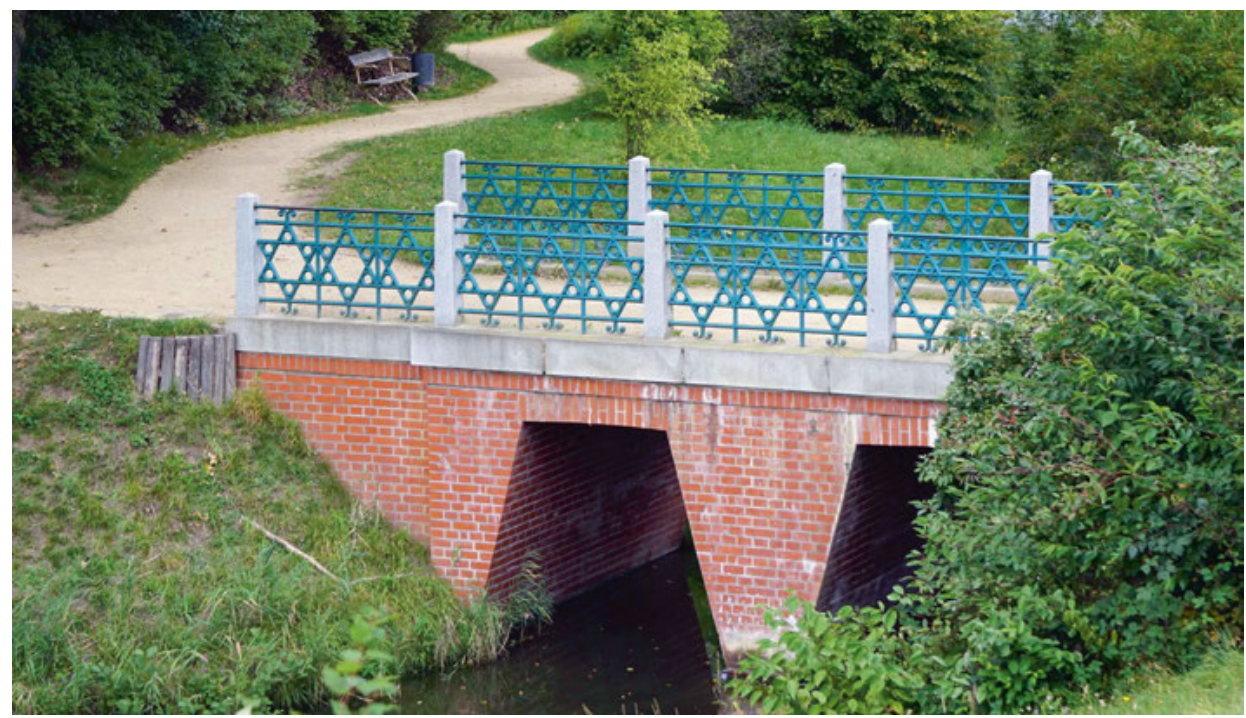

VIII Branitz: Mauerwerkbrücke: Verfärbungen nur durch undichte Fugen oder durch eine untüchtige Abdichtung? (G3) (G4) (G5) (M1) (H2). 


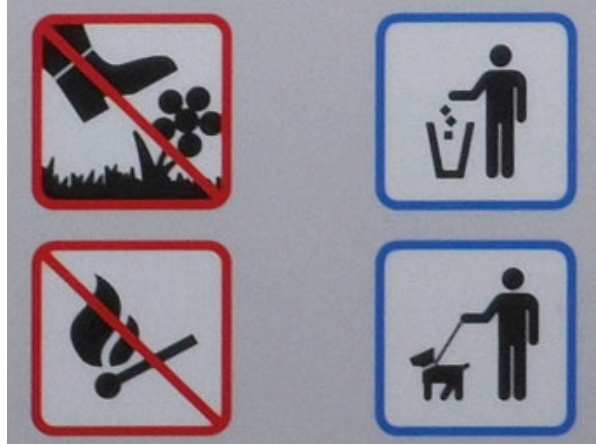

IX Piktogramme Parkordnungen SPSG.

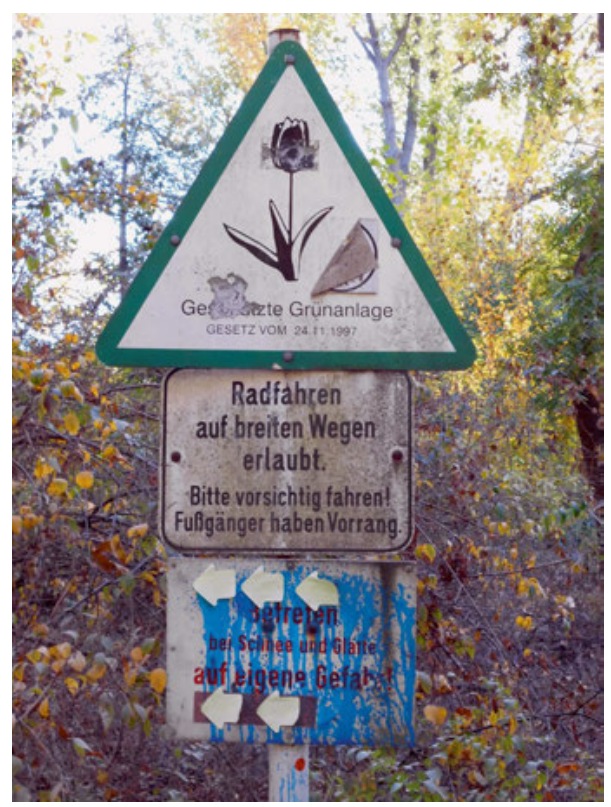

XI Tulpenschild und Ergänzungen, Großer Tiergarten, Eingang Bahnhof Zoologischer Garten.

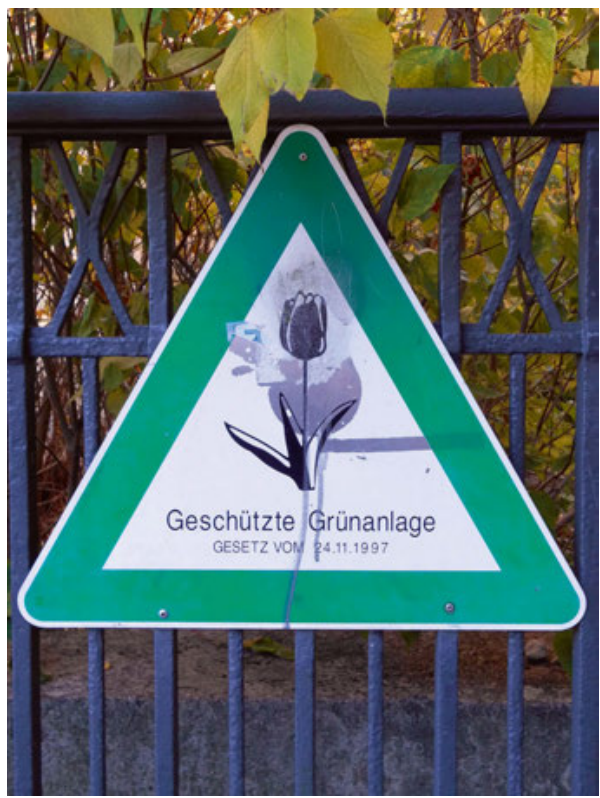

X Tulpenschild Berliner Grünanlagen.

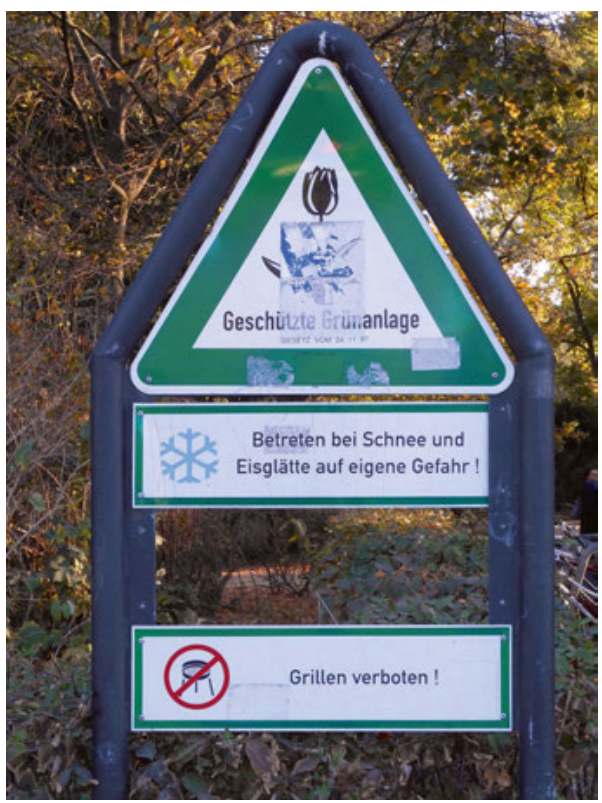

XII Tulpenschild und Ergänzungen, Großer Tiergarten, Eingang Straße des 17. Juni, nahe S-Bahnhof Tiergarten. 
s $\underline{\underline{1}}$ 䒺

- 해늘

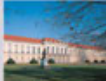

Biाn

Tilin if
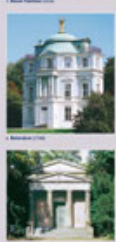

폴로-

\section{SCHLOSSGARTEN CHARLOTTENBURG}
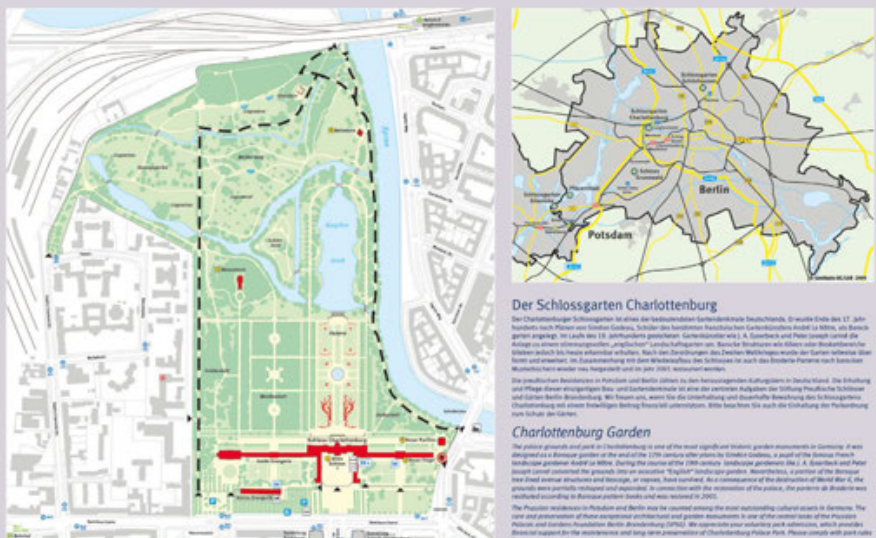

Der Schlossgarten Charlottenburg

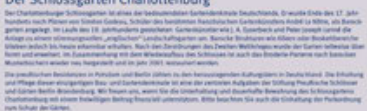

Charlottenburg Gorden

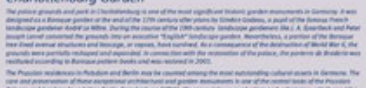

$\bullet=$

$\Delta$

XIII Infoschild und Parkordnung, Schlossgarten Charlottenburg. 


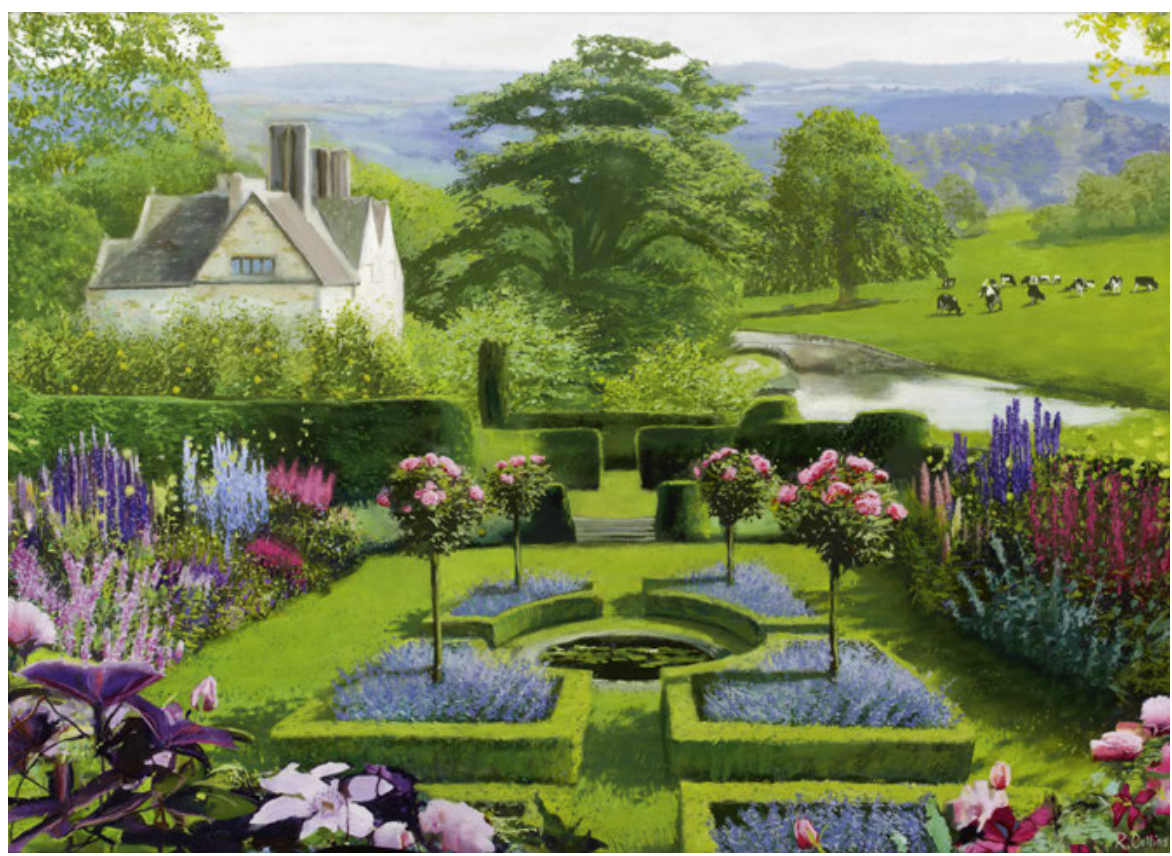

XIV

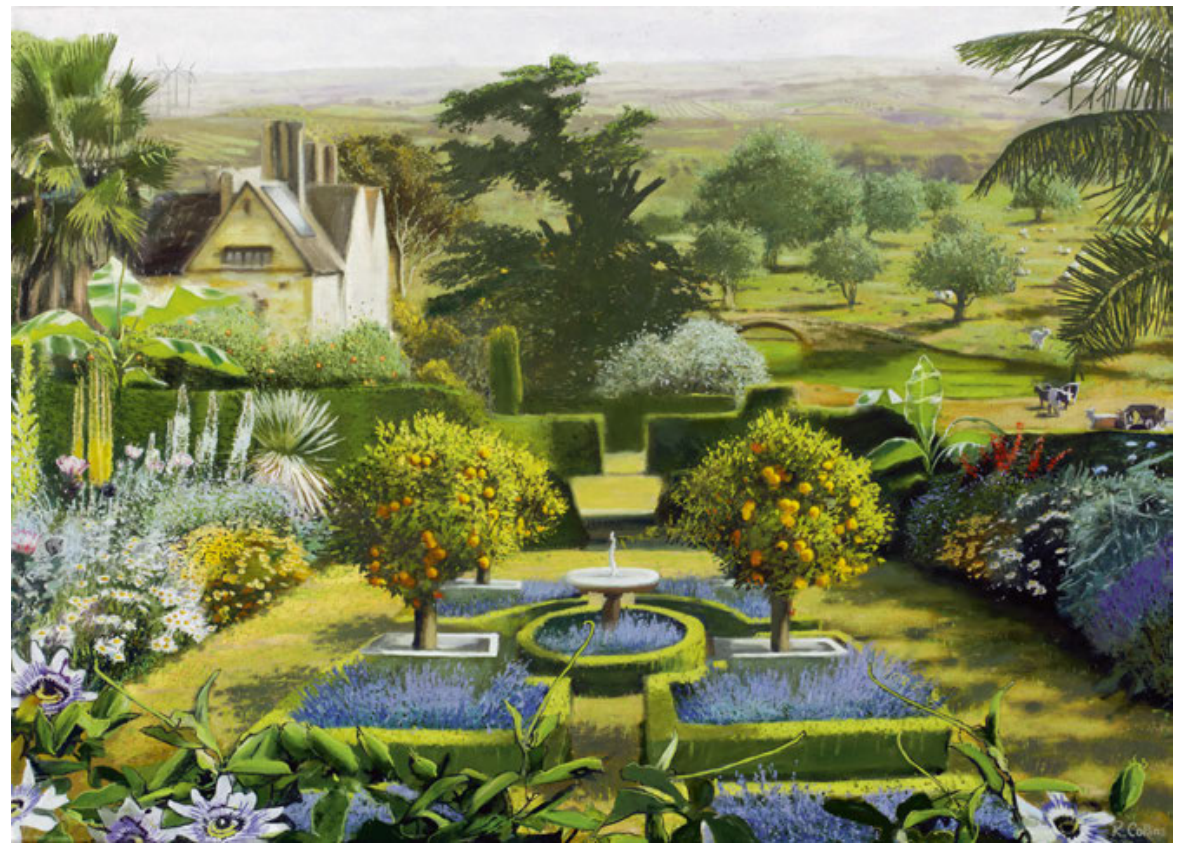




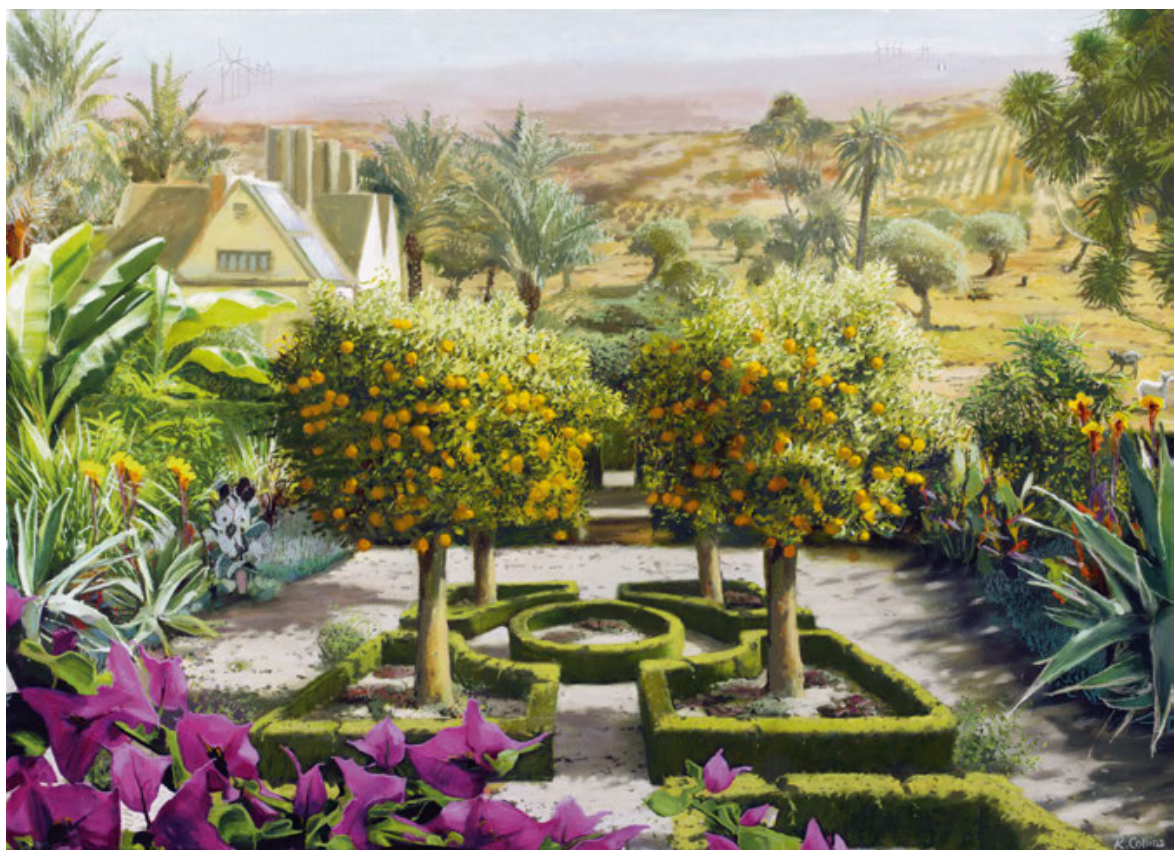

XVI

XIV-XVI The National Trust 2010 travelling exhibition on climate change entitled $>$ A plant in timer included three paintings, which feature a typical, but imaginary National Trust property, with a house set in parkland with lake. The first painting (Taf. XIV) shows the 2010 situation; the second painting (Taf. XV) a scenario of plus $2^{\circ} \mathrm{C}$; and the third painting (Taf. XVI) a scenario of plus $4^{\circ} \mathrm{C}$. 


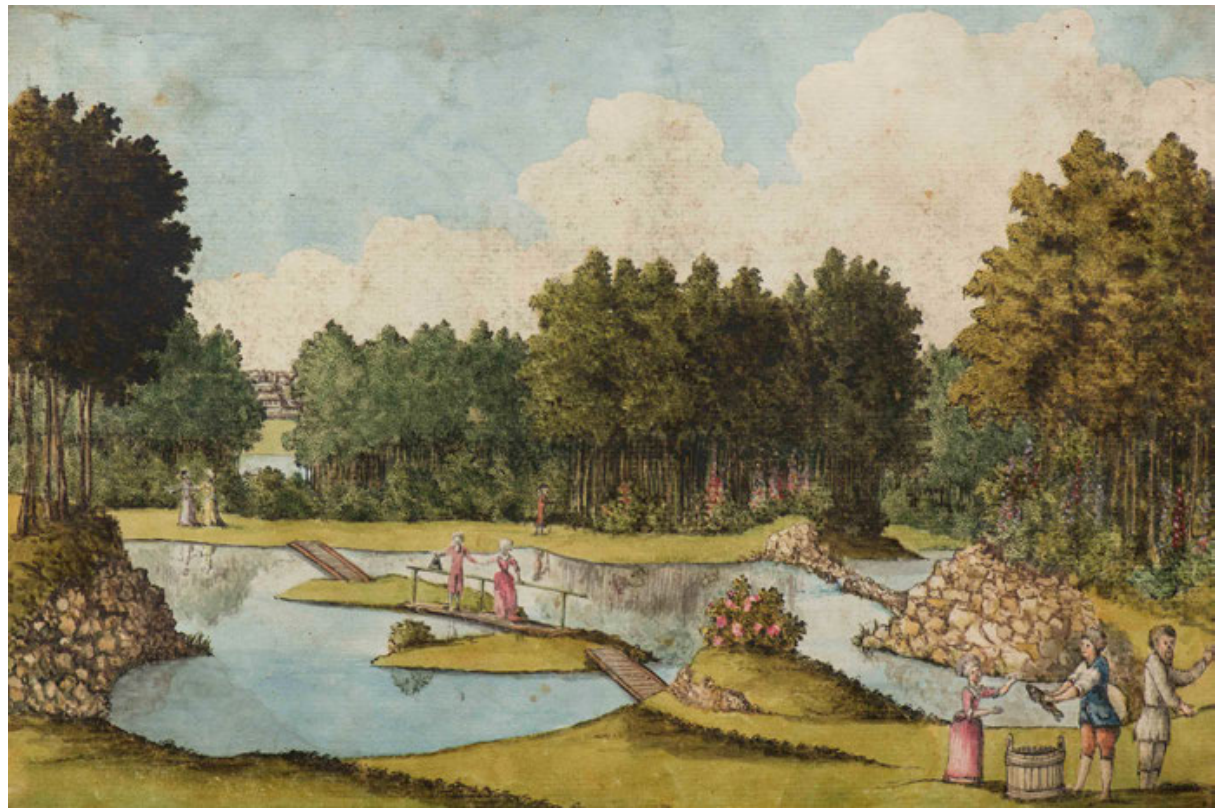

XVII A. T. Bolotov, P. A. Bolotov, View of the islets on the Lower pond in Bogoroditsk park. Page from the alum, Bogoroditsk. View of the estate of the counts Bobrinsky' 1786 Paper, water colour, ink, pen.

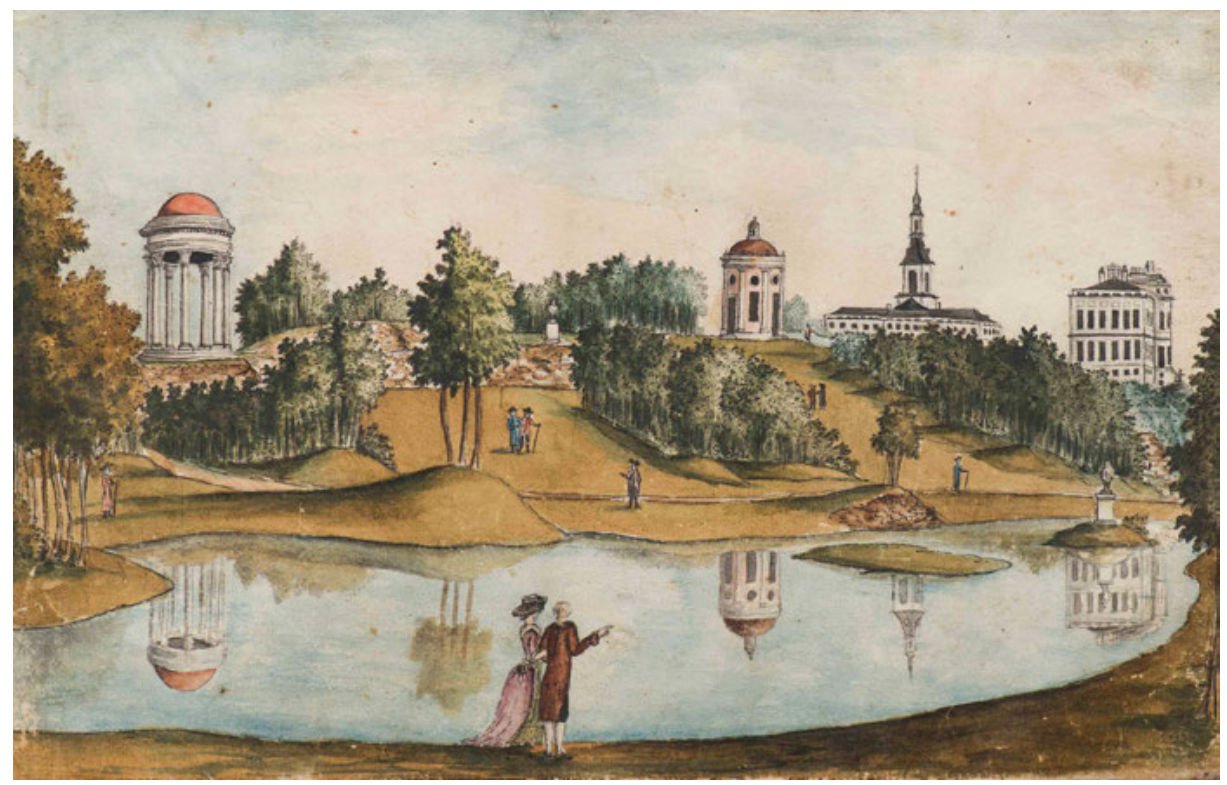

XVIII P. A. Bolotov, View of the rotunda, round pavilion, bell tower and palace from the $>$ Evening bench $<$ in Bogoroditsk park. Page from the album Bogoroditsk. View of the estate of the counts Bobrinsky, 1786-1787. 


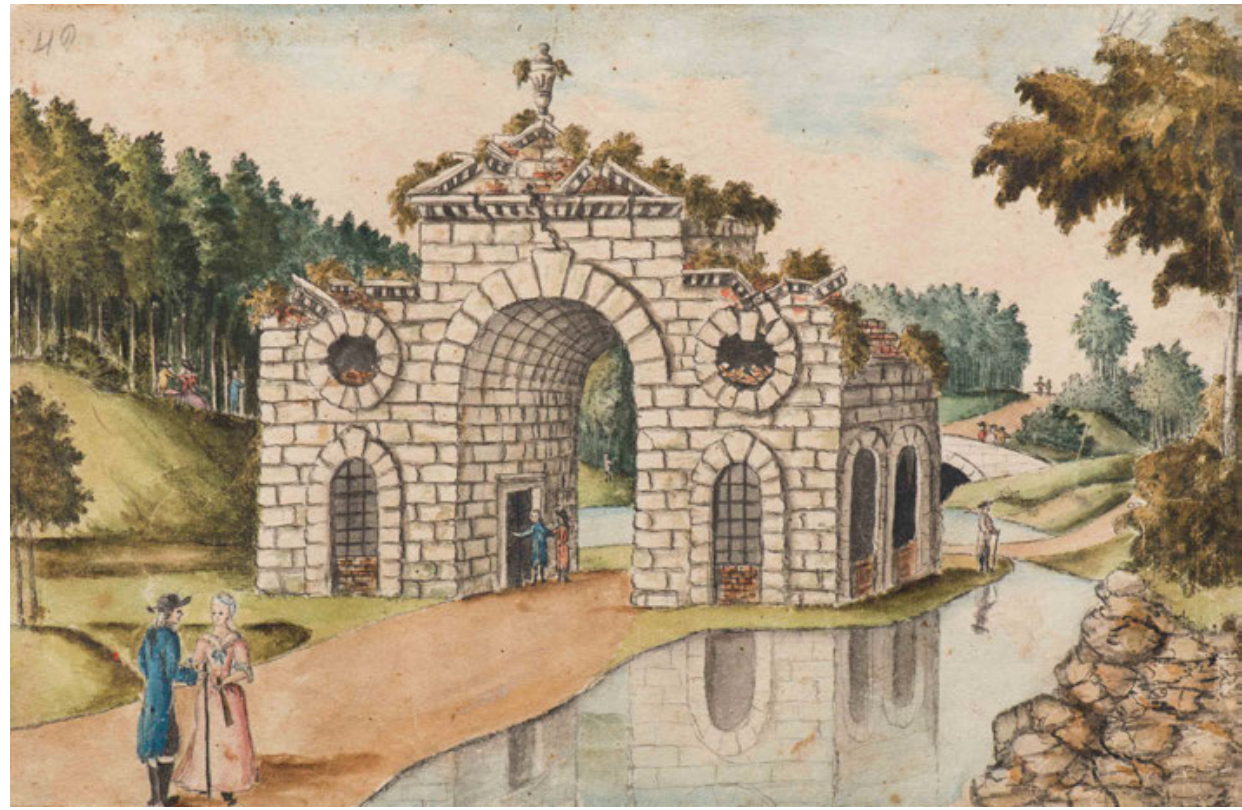

XIX A.T. Bolotov, P. A. Bolotov, View of the ruins of the dwellings of Ehi in the Ehinean valley in Bogoroditsk park. Page from the album Bogoroditsk. View of the estate of the counts Bobrinsky, 1786. Paper, water colour, ink, pen.

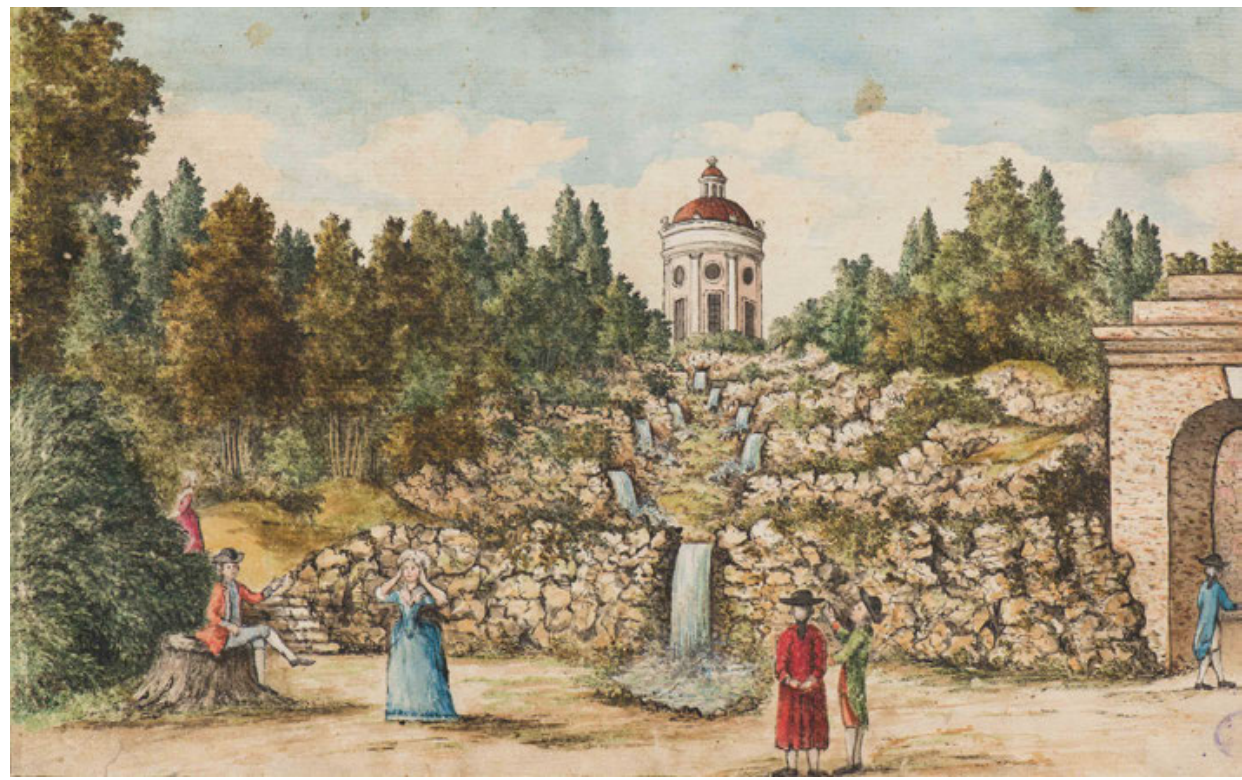

XX P. A. Bolotov, A. T. Bolotov, View of the waterfall and round pavilion in Bogoroditsk park. Page from the album Bogoroditsk. Views of the estate of the counts Bobrinsky, 1786. Paper, water colour, ink, pen. 
